\title{
RP-HPLC Method for Determination of Several NSAIDs and Their Combination Drugs
}

\author{
Prinesh N. Patel, Gananadhamu Samanthula, Vishalkumar Shrigod, \\ Sudipkumar C. Modh, and Jainishkumar R. Chaudhari
}

Department of Pharmaceutical Analysis, National Institute of Pharmaceutical Education and Research (NIPER), Balanagar, Hyderabad, Andhra Pradesh 500037, India

Correspondence should be addressed to Gananadhamu Samanthula; gana@niperhyd.ac.in

Received 29 June 2013; Accepted 13 October 2013

Academic Editor: Andrew Shalliker

Copyright (C) 2013 Prinesh N. Patel et al. This is an open access article distributed under the Creative Commons Attribution License, which permits unrestricted use, distribution, and reproduction in any medium, provided the original work is properly cited.

An RP-HPLC method for simultaneous determination of 9 NSAIDs (paracetamol, salicylic acid, ibuprofen, naproxen, aceclofenac, diclofenac, ketorolac, etoricoxib, and aspirin) and their commonly prescribed combination drugs (thiocolchicoside, moxifloxacin, clopidogrel, chlorpheniramine maleate, dextromethorphan, and domperidone) was established. The separation was performed on Kromasil C18 $(250 \times 4.6 \mathrm{~mm}, 5 \mu \mathrm{m})$ at $35^{\circ} \mathrm{C}$ using $15 \mathrm{mM}$ phosphate buffer $\mathrm{pH} 3.25$ and acetonitrile with gradient elution at a flow rate of $1.1 \mathrm{~mL} / \mathrm{min}$. The detection was performed by a diode array detector (DAD) at $230 \mathrm{~nm}$ with total run time of $30 \mathrm{~min}$. Calibration curves were linear with correlation coefficients of determination $\left(r^{2}\right)>0.999$. Limit of detection (LOD) and Limit of quantification (LOQ) ranged from 0.04 to $0.97 \mu \mathrm{g} / \mathrm{mL}$ and from 0.64 to $3.24 \mu \mathrm{g} / \mathrm{mL}$, respectively. As an application tool of quality by design, full factorial experimental design was used for the testing of robustness of the method. The prediction profiler correlating various parameters and responses was established from the results of design of experiments (DOE).

\section{Introduction}

Nonsteroidal anti-inflammatory drugs (NSAIDs) are among the most frequently prescribed drugs worldwide and are used for relief of inflammatory, chronic (e.g., rheumatoid arthritis, osteoarthritis, and gout), and acute (e.g., headache, postoperative pain, and orthopedic fractures) pain conditions [1]. NSAIDs formulations are also available as over-the counter pharmaceutical preparations. The anti-inflammatory activity of NSAIDs and most of their other pharmacological effects are related to the inhibition of the conversion of arachidonic acid to prostaglandins, which are mediators of the inflammatory process. NSAIDs are potent inhibitors of cyclooxygenase in vitro and in vivo, thereby decreasing the synthesis of prostaglandins, prostacyclin, and thromboxane products [2]. Table 1 represents the classification of NSAIDs based on their chemical structure [3].

The growing demand for NSAIDs stimulates higher level of quality control of these therapeutic substances and preparations. Hence, there is need to develop new analytical methods for qualitative and quantitative analysis of NSAIDs and their combination drugs. There are a number of liquid chromatographic methods reported in the literature [4-52] for the individual assays of these drugs and also for the some of their combinations but so far no method has been reported for the simultaneous determination of cited NSAIDs in the presence of selected commonly prescribed combination drugs. In light of the increasing number of combinations, these separation procedures are extremely incompetent. Some attempts have been made to develop single method determination of several NSAIDs in biological samples like Hirai et al. who developed a HPLC method for quantification of 12 NSAIDs in urine samples [53], Lapicque et al. who reported a HPLC method for quantification of sixteen NSAIDs in plasma [54], and Kazemifard and Moore who developed a highly sensitive HPLC method with amperometric detection in plasma samples [55]. GC-MS method has also been reported for some NSAIDs in water samples [56] and plasma and urine samples [57]. It is apparent that a more convergent method is required in order to make these procedures more straightforward and efficient for the estimation of NSAIDs and their combination drugs in their formulations. 
TABLE 1: Chemical classification of NSAIDs.

\begin{tabular}{ll}
\hline Class & Drugs \\
\hline Salicylic acid derivatives & $\begin{array}{l}\text { Acetylsalicylic acid (aspirin), salicylamide, sodium } \\
\text { salicylate }\end{array}$ \\
$\begin{array}{l}\text { Aniline and p-aminophenol derivatives aniline and } \\
\text { p-aminophenol derivatives }\end{array}$ & Paracetamol, phenacetin \\
Pyrazolone derivatives & Phenylbutazone, propyphenazone \\
2-Arylpropionic acids derivatives (profens) & Ibuprofen, flurbiprofen, ketoprofen, naproxen \\
Enolic acid derivatives & Meloxicam, piroxicam, tenoxicam, droxicam, \\
lornoxicam & Indometacin, diclofenac, aceclofenac, etodolac, \\
Arylalkanoic acids derivatives & nabumetone, sulindac \\
N-Arylanthranilic acids (fenamic acids) & $\begin{array}{l}\text { Mefenamic acid, tolfenamic acid, meclofenamic acid, } \\
\text { flufenamic acid }\end{array}$ \\
Selective COX-2 inhibitors (Coxibs) & Celecoxib, rofecoxib, etoricoxib, valdecoxib, parecoxib \\
Naphthylbutanone derivatives & Nabumetone \\
Sulphonanilides & Nimesulide \\
Benzoxazocine derivatives & Nefopam \\
\hline
\end{tabular}

We have developed a RP-HPLC method for the quantification of fifteen drugs (NSAIDs: paracetamol (PCM), salicylic acid (SA), ibuprofen (IBF), naproxen (NPX), aceclofenac (ACF), diclofenac (DCF), ketorolac (KTL), etoricoxib (ETC), and aspirin (ASP) and commonly prescribed combination drugs: thiocolchicoside (THC), moxifloxacin (MXF), clopidogrel (CLP), chlorpheniramine maleate (CPM), dextromethorphan (DXM), and domperidone (DOM) (structures are shown in Figure 1)) using design of experiments (DOE) approach for robustness testing of the method. To assess the effect of method parameters on chromatographic separation of all the drugs, statistically designed experiments were performed by varying different method parameters such as buffer concentration, $\mathrm{pH}$ of mobile phase, flow rate, and column temperature. The developed method was able to determine the content of the cited drugs in different commercial dosage forms. This method would be useful for simultaneous determination of these drugs in different single or compounded formulations.

\section{Materials and Methods}

2.1. Materials and Reagents. Active pharmaceutical ingredients were kindly obtained as gift samples from MSN Laboratories Ltd., Alembic Ltd., Mayer Lab chem., Maurer Wockhardt, Sri Krishna Pharmaceuticals, and Dr. Reddy's Laboratories Ltd. HPLC grade acetonitrile (ACN) was obtained from Merck, India. High purity water was prepared using Milli-Q gradient ultrapure water system (Billerica, MA, USA).

2.2. Chromatography. The experiments were performed on waters e2695 separation module with waters 2998 photodiode array (PDA) detector. The chromatographic and the integrated data were recorded using empower 2 software. Chromatographic separations were performed on Kromasil C18
TABLE 2: Gradient programme.

\begin{tabular}{ccccc}
\hline & Time (min.) & Flow (mL/min.) & \%A & $\% \mathrm{~B}$ \\
\hline 1 & & 1.10 & 80.0 & 20.0 \\
2 & 3.0 & 1.10 & 80.0 & 20.0 \\
3 & 16.0 & 1.10 & 45.0 & 55.0 \\
4 & 17.0 & 1.10 & 35.0 & 65.0 \\
5 & 26.0 & 1.10 & 10.0 & 90.0 \\
6 & 27.0 & 1.10 & 80.0 & 20.0 \\
7 & 30.0 & 1.10 & 80.0 & 20.0 \\
\hline
\end{tabular}

TABLE 3: Chromatographic parameters for the assayed drugs.

\begin{tabular}{lcccc}
\hline Drug & Rt & Rs & $N$ & Tf \\
\hline PCM & 3.34 & & 8439 & 1.13 \\
THC & 5.91 & 11.72 & 7107 & 1.00 \\
SA & 7.12 & 6.9 & 16342 & 0.92 \\
MCX & 8.77 & 4.16 & 34614 & 1.19 \\
ASP & 9.14 & 3.28 & 31249 & 1.05 \\
DOM & 10.82 & 6.75 & 64678 & 1.28 \\
CPM & 11.47 & 2.74 & 40661 & 1.50 \\
DXM & 12.34 & 3.66 & 37689 & 1.58 \\
KTL & 14.98 & 14.06 & 145673 & 1.06 \\
ETC & 15.73 & 1.67 & 144829 & 1.03 \\
NPX & 18.43 & 17.66 & 188879 & 1.22 \\
ACF & 19.57 & 8.69 & 301257 & 1.05 \\
DCF & 21.14 & 8.62 & 321291 & 1.08 \\
IBF & 21.91 & 4.67 & 311614 & 1.06 \\
CLP & 25.36 & 19.73 & 328259 & 1.07 \\
\hline
\end{tabular}

Rt: retention time, Rs: resolution, $N$ : number of theoretical plates, and Tf: tailing factor.

$(250 \times 4.6 \mathrm{~mm}, 5.0 \mu \mathrm{m})$ column at $35^{\circ} \mathrm{C}$ using $15 \mathrm{mM}$ phosphate buffer pH 3.25 (A) and acetonitrile (B) as mobile phase 
<smiles>CC(=O)Oc1ccccc1C(=O)Oc1ccccc1</smiles>

Ibuprofen<smiles>O=C(O)Cc1ccccc1Nc1c(Cl)cccc1Cl</smiles>

Diclofenac<smiles>O=C(O)COC(=O)Cc1ccccc1Nc1c(Cl)cccc1Cl</smiles>

Aceclofenac<smiles>CN(C)CCC(c1ccc(Cl)cc1)c1ccccn1</smiles>

Chlorpheniramine<smiles>COc1ccc2c(c1)C1(CCCCC1)C[C@@H]1CCC[C@H]2N1C</smiles>

Dextromethorphan<smiles>COc1c(O[C@@H]2O[C@H](CO)[C@@H](O)[C@H](O)[C@H]2O)cc2c(c1OC)-c1ccc(SC)c(=O)cc1C(NC(C)=O)CC2</smiles>

Thiocolchicoside<smiles>COc1c(N2C[C@H]3CCCN[C@H]3C2)c(F)cc2c(=O)c(C(=O)O)cn(C3CC3)c12</smiles>

Moxifloxacin<smiles>O=C(c1ccccc1)c1ccc2n1CCC2C(=O)O</smiles>

Ketorolac<smiles>COC(=O)[C@H](c1ccccc1Cl)N1CCc2sccc2C1</smiles>

Clopidogrel<smiles>COc1ccc2cc([C@@H](C)C(=O)O)ccc2c1</smiles>

Naproxen<smiles>CC(=O)Nc1ccc(O)cc1</smiles>

Paracetamol<smiles>O=c1[nH]c2ccccc2n1CCCN1CCC(n2c(=O)[nH]c3cc(Cl)ccc32)CC1</smiles>

Domperidone<smiles>Cc1ccc(-c2ncc(Cl)cc2-c2ccc(S(C)(=O)=O)cc2)cn1</smiles>

Etoricoxib

FIgURE 1: Chemical structure of the studied drugs.

with gradient elution at a flow rate of $1.1 \mathrm{~mL} / \mathrm{min}$. Gradient Programme is shown in Table 2. Detection of all the components was carried out at $230 \mathrm{~nm}$ with adequate sensitivity.

2.3. Preparation of Stock and Calibration Solutions. Composite stock solution was prepared by dissolving $25 \mathrm{mg}$ of PCM and NPX, $50 \mathrm{mg}$ of THC, SA, MCX, ASP, DOM, CPM,
KTL, ETC, ACF, DCF, \& CLP, and $100 \mathrm{mg}$ of IBF \& DXM in $\mathrm{ACN}$ : water $(70: 30 \mathrm{v} / \mathrm{v})$. Using this stock solution, serial dilutions were made to get 8 different concentrations $(1,2.5,5$, $10,20,30,40$, and $50 \mu \mathrm{g} / \mathrm{mL}$ for PCM \& NPX, $4,10,20,40,80$, 120,160 , and $200 \mu \mathrm{g} / \mathrm{mL}$ for IBF \& DXM, and $2,5,10,20,40$, 60,80 , and $100 \mu \mathrm{g} / \mathrm{mL}$ for THC, SA, MCX, ASP, DOM, CPM, KTL, ETC, ACF, DCF, \& CLP) to construct calibration curve. 
TABLE 4: Linearity data.

\begin{tabular}{lccc}
\hline Drug & Range $(\mu \mathrm{g} / \mathrm{mL})$ & Regression equation & Correlation coefficient $\left(R^{2}\right)$ \\
\hline PCM & $1-50$ & $y=21951 x-18472$ & 0.9992 \\
THC & $2-100$ & $y=16869 x-14679$ & 0.9996 \\
SA & $2-100$ & $y=23301 x-13847$ & 0.9995 \\
MCX & $2-100$ & $y=13062 x-22221$ & 0.9997 \\
ASP & $2-100$ & $y=17800 x-15202$ & 0.9992 \\
DOM & $2-100$ & $y=15840 x-10582$ & 0.9998 \\
CPM & $2-100$ & $y=11350 x-12712$ & 0.9994 \\
DXM & $4-200$ & $y=8476 x-11714$ & 0.9997 \\
KTL & $2-100$ & $y=7035 x-4477$ & 0.9994 \\
ETC & $2-100$ & $y=37259 x-19456$ & 0.9998 \\
NPX & $1-50$ & $y=17840 x+16511$ & 0.9996 \\
ACF & $2-100$ & $y=16004 x+25084$ & 0.9995 \\
DCF & $2-100$ & $y=18575 x-11191$ & 0.9995 \\
IBF & $4-200$ & $y=8957 x-13038$ & 0.9993 \\
CLP & $2-100$ & $y=11627 x-14346$ & 0.9992 \\
\hline
\end{tabular}

TABLE 5: LOD and LOQ of the drugs studied.

\begin{tabular}{|c|c|c|c|c|c|c|c|c|c|c|c|c|c|c|c|}
\hline Drug $(\mu \mathrm{g} / \mathrm{mL})$ & PCM & THC & SA & MCX & ASP & DOM & $\mathrm{CPM}$ & DXM & KTL & ETC & NPX & $\mathrm{ACF}$ & DCF & IBF & CLP \\
\hline LOD & 0.19 & 0.37 & 0.39 & 0.48 & 0.41 & 0.37 & 0.52 & 0.97 & 0.57 & 0.19 & 0.04 & 0.36 & 0.32 & 0.69 & 0.53 \\
\hline LOQ & 0.64 & 1.22 & 1.3 & 1.61 & 1.36 & 1.24 & 1.75 & 3.24 & 1.9 & 0.65 & 0.14 & 1.18 & 1.05 & 2.3 & 1.77 \\
\hline
\end{tabular}

Final dilutions of all drugs were made in phosphate buffer pH $3.25: \mathrm{ACN}(80: 20 \mathrm{v} / \mathrm{v})$. Responses were measured as peak areas and plotted against concentration.

\section{Results and Discussion}

3.1. Method Development and Optimization. Experiments were carried out to optimize the experimental parameters affecting the chromatographic separation of all the drugs. Initial experiments showed better resolution and peak shape with acetonitrile compared with the methanol. Therefore, acetonitrile was used as an organic modifier for method development.

The effects of different $\mathrm{pH}$ and mobile phase composition were tried to improve the resolution and peak symmetry, such as ammonium acetate, ammonium formate, phosphate, and trifluoroacetic acid with variable $\mathrm{pH}$ along with altered composition for \% organic, that were tested for complete chromatographic resolution of all 15 drugs.

With ammonium acetate buffer $\mathrm{pH} 4$, there was not an adequate separation between CPM, KTL, and DXM whereas with phosphate buffer $\mathrm{pH} 2.8$ there was no separation at all between SA and ASP. As there were fifteen analytes with diverse physicochemical properties, trials were done to optimize the gradient to have the maximum resolution in the shortest possible run time. From all the trials, pH 3.25 with proposed gradient programme gave the best resolution for all the analytes in run time of $30 \mathrm{~min}$.

The suitability of the proposed method was checked on Phenomenex C8, Grace Genesis Phenyl, Grace C18, Hiber C18, and Kromacil C18 columns with the same dimensions. C8 column led to a very poor resolution of almost all drugs and with phenyl column, there was no separation at all between CPM-DOM and ETC-KTL. Use of Hiber C18 column with proposed gradient resulted in poor separation of ASP-MCX.

Finally, the use of phosphate buffer $\mathrm{pH} 3.25$ with proposed gradient on Kromacil C18 column provided an adequate peak separation, with less tailing, and resulted in the best resolution amongst the buffers tested. A typical chromatogram showing the separation of peaks of all 15 drugs is depicted in Figure 2.

3.2. Validation of the Method. The method was validated by evaluating specificity, linearity, precision, accuracy, limit of detection (LOD), limit of quantification (LOQ), robustness, and system suitability parameters in accordance with the ICH guideline Q2 (R1) [58].

3.2.1. System Suitability. The system suitability was checked by six replicate injections (standard solution of mixture of $40 \mu \mathrm{g} / \mathrm{mL}$ each drug). The system is deemed to be suitable for use as the tailing factor was less than 1.5 and resolution was greater than 2 for all the drugs. The chromatographic parameters for the drugs are reported in Table 3.

3.2.2. Linearity. The linearity of detector response to different concentrations of drugs was studied in the 8 different concentrations. The samples were analyzed in triplicates at all concentrations. Calibration curves were constructed and the correlation coefficient values of all the studied drugs were observed to be $\geq 0.999$. The regression analysis data for calibration curves were calculated using the peak areas and the data are shown in Table 4. 


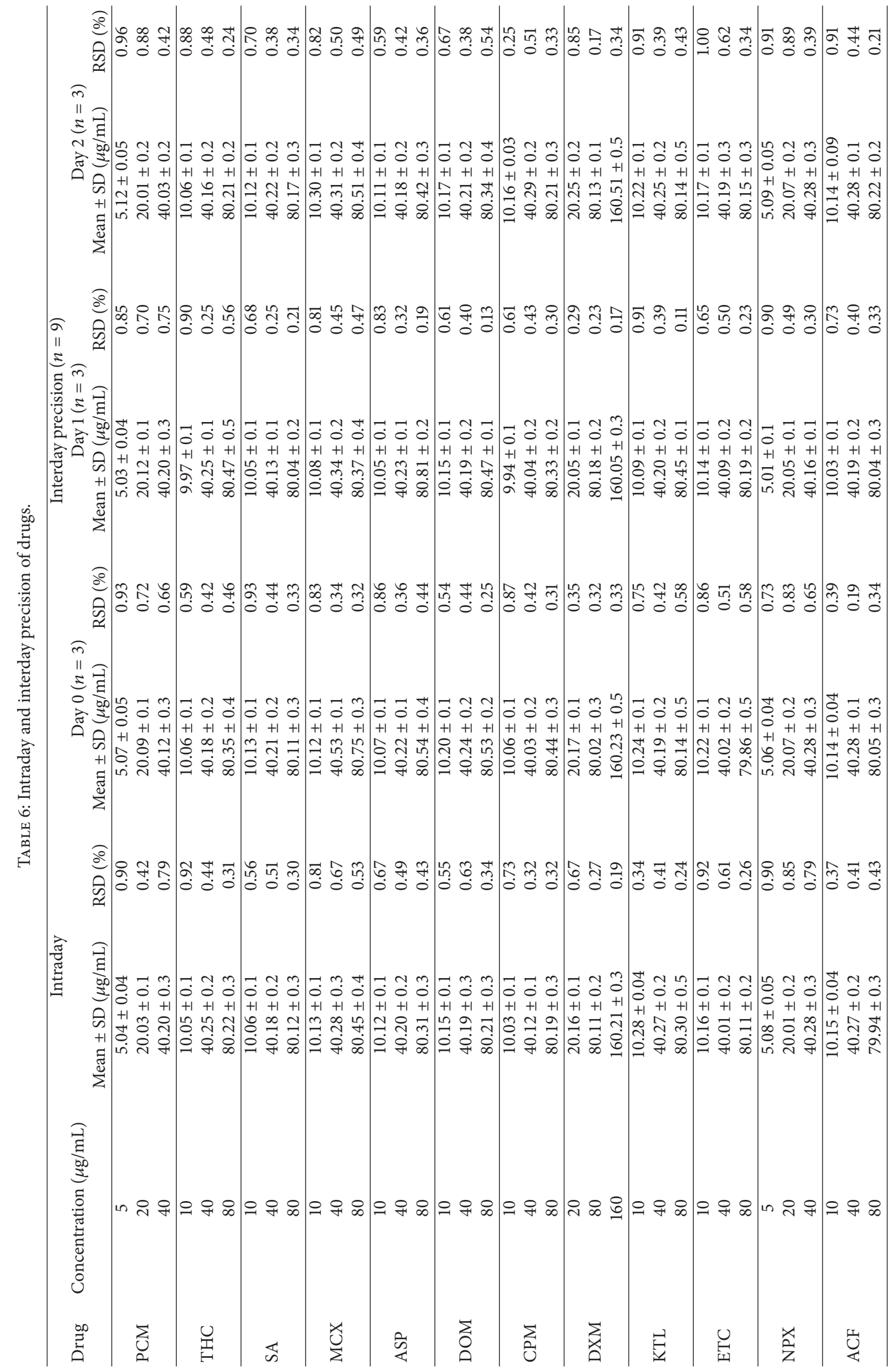




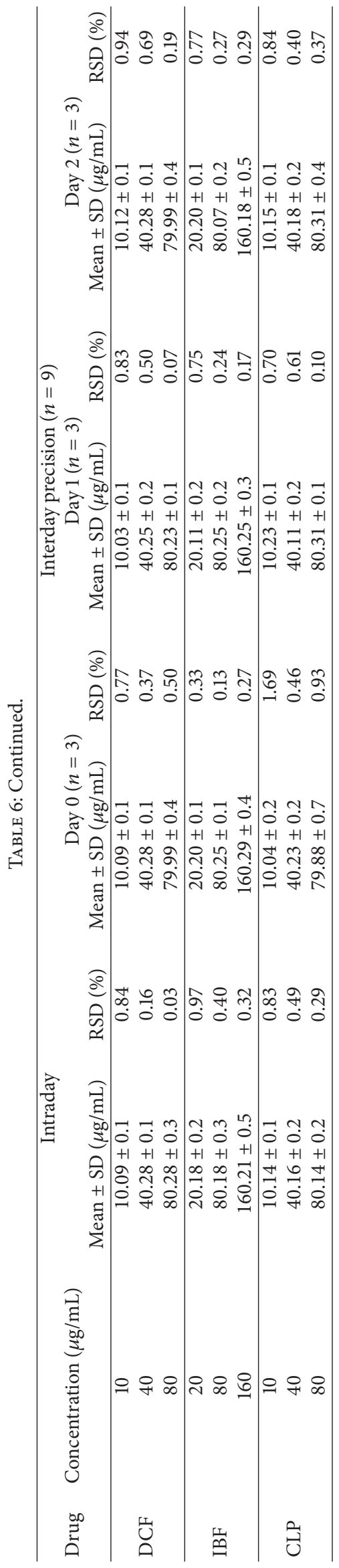




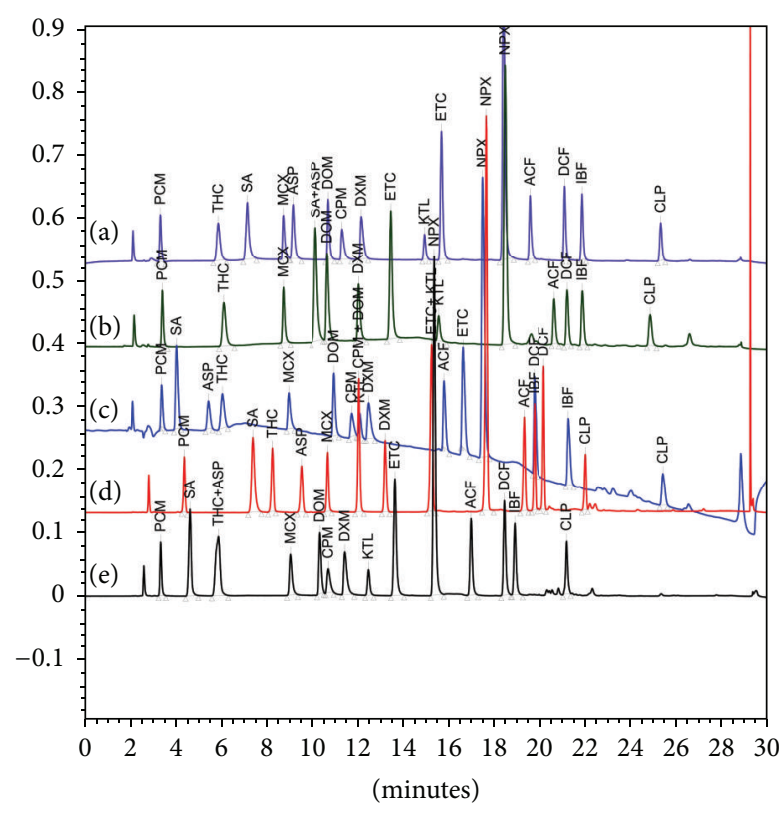

FIGURE 2: HPLC chromatograms showing pattern of separation in different trials (detection at $230 \mathrm{~nm}$ ). (a) Final conditions chromatogram: pH 3.25 (phosphate buffer), Kromacil C18 column; (b) pH 2.8 (phosphate buffer), Kromacil column; (c) pH 4.0 (ammonium acetate buffer), Kromacil C18 column; (d) pH 3.25 (phosphate buffer), Grace Genesis Phenyl column; (e) pH 3.25 (phosphate buffer), Grace C18 Phenyl column.

3.2.3. Limit of Detection (LOD) and Limit of Quantification (LOQ). The LOD and LOQ were determined based on signal-to-noise ratio using analytical response of 3 and 10 times of the background noise, respectively. The data are shown in Table 5.

3.2.4. Precision. The intra-day precision was determined by injecting five replicates of three standard solutions covering low, medium, and high concentration levels on a single day. The interday precision of the proposed method was performed by chromatographing standard solutions of the same concentration levels analyzed in triplicate on each of the three consecutive days. The mean value of the concentration and $\%$ relative standard deviation (\% RSD) are summarized in Table 6.

3.2.5. Accuracy. Accuracy was determined by applying the described method to synthetic mixtures of excipients (lactose, mannitol, maize starch, microcrystalline cellulose, magnesium carbonate, magnesium stearate, silicon dioxide, and titanium dioxide) to which known amounts of each drug at level described in the table were added and analyzed by the proposed method. The accuracy was then calculated as the percentage of each drug recovered by the assay (Table 7).

3.2.6. Robustness. Statistically designed experiments were performed to screen robustness of an analytical method. A full factorial design of experiments containing all possible combinations between the 4 factors and their 2 levels, leading
TABLE 7: Accuracy data expressed as the percentage recovery of the amount added.

\begin{tabular}{|c|c|c|c|}
\hline Drug & Amount added $(\mu \mathrm{g} / \mathrm{mL})$ & Recovery (\%) & RSD (\%) \\
\hline \multirow{3}{*}{ PCM } & 10 & 99.97 & 0.76 \\
\hline & 25 & 99.93 & 0.21 \\
\hline & 50 & 100.15 & 0.41 \\
\hline \multirow{3}{*}{ THC } & 25 & 100.21 & 0.27 \\
\hline & 50 & 100.38 & 0.38 \\
\hline & 100 & 100.59 & 0.41 \\
\hline \multirow{3}{*}{ SA } & 25 & 101.27 & 1.21 \\
\hline & 50 & 100.63 & 0.26 \\
\hline & 100 & 99.90 & 0.24 \\
\hline \multirow{3}{*}{ MCX } & 25 & 99.69 & 0.54 \\
\hline & 50 & 100.41 & 0.32 \\
\hline & 100 & 100.45 & 0.55 \\
\hline \multirow{3}{*}{ ASP } & 25 & 101.13 & 0.70 \\
\hline & 50 & 99.70 & 0.34 \\
\hline & 100 & 100.02 & 0.21 \\
\hline \multirow{3}{*}{ DOM } & 25 & 99.66 & 0.72 \\
\hline & 50 & 99.85 & 0.45 \\
\hline & 100 & 100.40 & 0.77 \\
\hline \multirow{3}{*}{$\mathrm{CPM}$} & 25 & 101.51 & 0.81 \\
\hline & 50 & 99.76 & 0.36 \\
\hline & 100 & 99.85 & 0.42 \\
\hline \multirow{3}{*}{ DXM } & 50 & 101.35 & 1.10 \\
\hline & 100 & 100.55 & 0.14 \\
\hline & 150 & 99.88 & 0.28 \\
\hline \multirow{3}{*}{ KTL } & 25 & 101.09 & 1.43 \\
\hline & 50 & 99.53 & 0.26 \\
\hline & 100 & 99.85 & 0.21 \\
\hline \multirow{3}{*}{ ETC } & 25 & 98.65 & 0.75 \\
\hline & 50 & 100.51 & 0.22 \\
\hline & 100 & 100.49 & 0.31 \\
\hline \multirow{3}{*}{ NPX } & 10 & 98.80 & 1.29 \\
\hline & 25 & 100.88 & 0.61 \\
\hline & 50 & 100.51 & 0.20 \\
\hline \multirow{3}{*}{$\mathrm{ACF}$} & 25 & 100.04 & 0.67 \\
\hline & 50 & 100.75 & 0.21 \\
\hline & 100 & 100.29 & 0.05 \\
\hline \multirow{3}{*}{ DCF } & 25 & 101.91 & 0.79 \\
\hline & 50 & 100.02 & 0.64 \\
\hline & 100 & 99.95 & 0.35 \\
\hline \multirow{3}{*}{ IBF } & 50 & 100.71 & 0.33 \\
\hline & 100 & 99.76 & 0.11 \\
\hline & 150 & 99.67 & 0.14 \\
\hline \multirow{3}{*}{ CLP } & 25 & 99.28 & 0.96 \\
\hline & 50 & 99.81 & 0.75 \\
\hline & 100 & 99.84 & 0.18 \\
\hline
\end{tabular}

to $n=2^{4}=16$ experiments, was used to evaluate the robustness of the method. The variables evaluated in the study include $\mathrm{pH}$, flow rate, column temperature, and buffer 
TABLE 8: Full factorial design of experiments for robustness.

\begin{tabular}{lccccc}
\hline Exp. & Pattern & Flow rate $(\mathrm{mL} / \mathrm{min})$. & $\mathrm{pH}$ & Buffer strength $(\mathrm{mM})$ & Temperature $\left({ }^{\circ} \mathrm{C}\right)$ \\
\hline 1 & +--- & 1.2 & 3.05 & 10 & 30 \\
2 & --++ & 1 & 3.05 & 10 & 40 \\
3 & +--+ & 1.2 & 3.05 & 20 & 30 \\
4 & --+- & 1 & 3.05 & 20 & 30 \\
5 & -++- & 1 & 3.45 & 20 & 40 \\
6 & -+++ & 1 & 3.45 & 20 & 30 \\
7 & +-+- & 1.2 & 3.05 & 20 & 40 \\
8 & --++ & 1 & 3.05 & 20 & 40 \\
9 & +-++ & 1.2 & 3.05 & 10 & 30 \\
10 & ++-- & 1.2 & 3.45 & 10 & 30 \\
11 & -+-- & 1 & 3.45 & 10 & 30 \\
12 & ---- & 1 & 3.05 & 20 & 40 \\
13 & ++-+ & 1.2 & 3.45 & 10 & 40 \\
14 & ++++ & 1.2 & 3.45 & 20 & 30 \\
15 & -+-+ & 1 & 3.45 & 3.45 & \\
16 & +++- & 1.2 & & & 30 \\
\hline
\end{tabular}

TABLE 9: Quantitative determination in pharmaceutical formulations.

\begin{tabular}{|c|c|c|c|c|c|}
\hline Formulation examined & API & Label claim (mg) & $\begin{array}{c}\text { Amount found } \\
(\text { Mean } \pm \text { SD }) \\
(\mathrm{mg})\end{array}$ & Recovery (\%) & $\begin{array}{c}\mathrm{RSD}(\%) \\
(n=6)\end{array}$ \\
\hline \multirow{2}{*}{ CLAVIX-AS tab } & CLP & 75 & $75.15 \pm 0.1$ & 100.17 & 0.14 \\
\hline & ASP & 150 & $150.04 \pm 0.5$ & 100.03 & 0.32 \\
\hline \multirow{3}{*}{ DEXA-P tab } & PCM & 125 & $124.90 \pm 0.3$ & 99.92 & 0.21 \\
\hline & CPM & 1 & $0.99 \pm 0.02$ & 98.97 & 1.7 \\
\hline & DXM & 5 & $5.07 \pm 0.1$ & 101.48 & 1.81 \\
\hline \multirow{2}{*}{ THIOCECLO tab } & $\mathrm{ACF}$ & 100 & $99.92 \pm 0.3$ & 99.92 & 0.32 \\
\hline & THC & 4 & $4.01 \pm 0.1$ & 100.33 & 1.37 \\
\hline \multirow{2}{*}{ CETADOM tab } & PCM & 500 & $499.61 \pm 0.8$ & 99.92 & 0.16 \\
\hline & $\mathrm{DOM}$ & 10 & $10.03 \pm 0.1$ & 100.33 & 0.9 \\
\hline \multirow{2}{*}{ MILFLOX PLUS eye drops } & MCX & 5 & $4.92 \pm 0.1$ & 98.4 & 1.74 \\
\hline & KTL & 5 & $5.05 \pm 0.1$ & 101 & 1.62 \\
\hline \multirow{2}{*}{ SUPAMOVE-4 cap } & $\mathrm{THC}$ & 4 & $4.02 \pm 0.1$ & 100.4 & 1.76 \\
\hline & DCF & 50 & $49.70 \pm 0.3$ & 99.39 & 0.58 \\
\hline \multirow{2}{*}{ ARTIGESIC tab } & IBU & 400 & $399.35 \pm 1.2$ & 99.84 & 0.31 \\
\hline & PCM & 325 & $325.30 \pm 0.9$ & 100.06 & 0.27 \\
\hline \multirow{2}{*}{ NUCOXIA-P tab } & ETC & 60 & $59.90 \pm 0.3$ & 99.84 & 0.53 \\
\hline & PCM & 500 & $500.21 \pm 0.6$ & 100.04 & 0.12 \\
\hline \multirow{2}{*}{ NAPRA-D tab } & NPX & 250 & $249.72 \pm 0.4$ & 99.89 & 0.16 \\
\hline & DOM & 10 & $9.98 \pm 0.2$ & 99.76 & 1.73 \\
\hline
\end{tabular}

strength. Table 8 represents pattern of the design of experiments. Resolution and tailing factor for all drugs in all 16 experiments were considered as responses. Data were analyzed in JMP (SAS institute) with analysis of variance (ANOVA) techniques and regression analysis combined with graphical illustrations used to determine the impact of the four variables of interest. The variables having a significant $(P<0.05)$ impact on the responses were obtained. Prediction profiler as shown in Figures 3 and 4 was one of the outcomes from the software to evaluate the impact of variables. The prediction profiler correlating various parameters and responses was obtained from the results of DOE. Based on the slope of the individual curve, impact of each variable could be easily determined. The larger the slope, the more the impact on the response.

Based on regression analysis of the data, it was concluded that $\mathrm{pH}$, buffer strength, and temperature were significant parameters affecting the resolution of THC and IBF and 


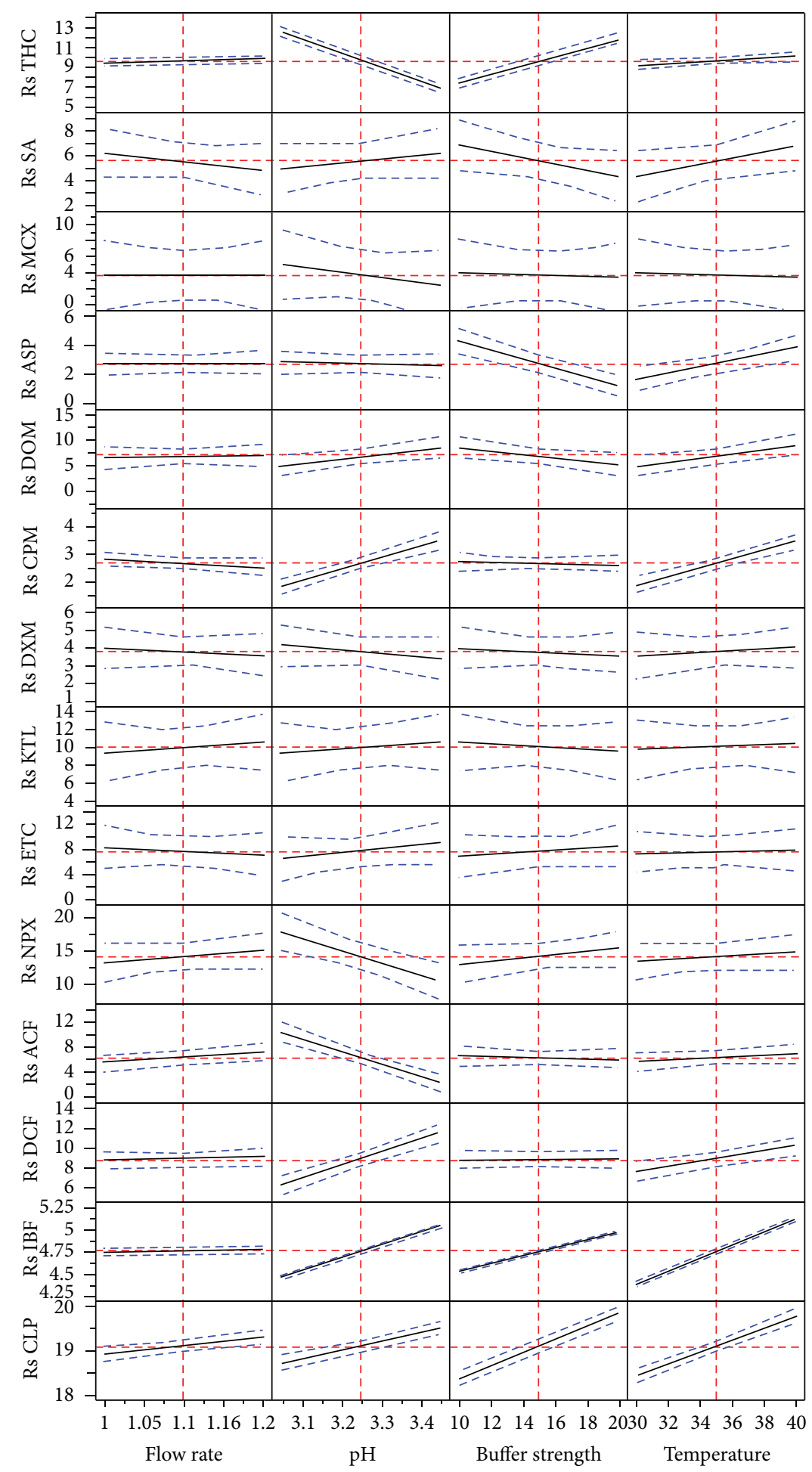

FIgURE 3: Prediction profiler for resolution.

tailing of NPX, IBF, \& ACF whereas $\mathrm{pH}$ and temperature had significant effect on resolution of DCF \& CPM and Tailing of DOM \& CPM. pH was significant factor for the resolution of NPX \& ACF and tailing of THC, SA, \& ASP. However, CLP resolution was significantly affected by all parameters studied. However, none of the factors had significant effect on resolution of SA, MCX, DXM, KTL, and ETC and tailing of MCF, KTL, ETC, and CLP.

3.2.7. Quantitative Determination in Pharmaceutical Formulations. The validated HPLC method was applied to the simultaneous determination of these drugs in market 


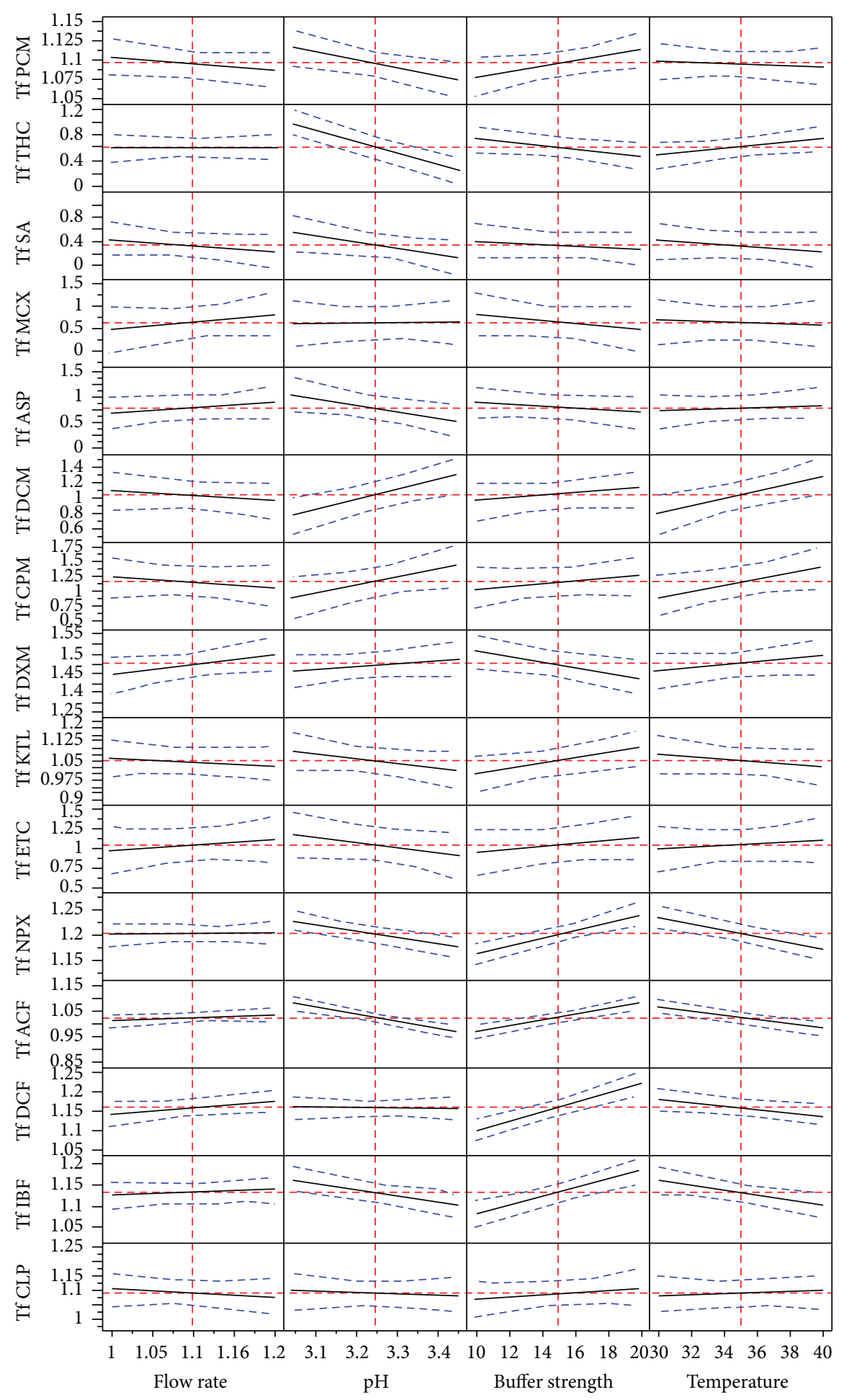

FIGURE 4: Prediction profiler for tailing factor.

formulations. Amount equivalent to one unit was weighed and diluted in ACN : water $(70: 30 \mathrm{v} / \mathrm{v})$, sonicated for $15 \mathrm{~min}$ and further dilutions were made with phosphate buffer $\mathrm{pH} 3.25: \mathrm{ACN}(80: 20 \mathrm{v} / \mathrm{v})$ to obtain concentrations within the linearity range. All the samples were filtered through whatman (GD/X25, polypropylene, $0.45 \mathrm{~mm}$ ) syringe filter, before injecting the samples into the HPLC instrument. The formulation assay results, expressed as a percentage of the label claim, are shown in Table 9. The results indicate that the amount of each drug in the tablets corresponds to the requirement of $90-110 \%$ of the label claim. 


\section{Conclusion}

A simple, accurate, precise, and robust RP-HPLC method has been developed and applied for simultaneous analysis of some NSAIDs and their combinations. The methodology was evaluated for specificity, linearity, precision, accuracy, and range in order to establish the suitability of the analytical method. Robustness of the method was evaluated using statistical experimental designs to designate the factors that influence the method's robustness significantly. The developed method was employed for simultaneous determination in their combined dosage forms. This method can be applicable in routine quality control of these drugs.

\section{Conflict of Interests}

The authors have no conflict of interests in this paper.

\section{Acknowledgments}

The authors are thankful to the Department of pharmaceuticals, Ministry of Chemicals and Fertilizers, Government of India, for providing the funds for research at NIPER, Hyderabad.

\section{References}

[1] B. McCarberg and A. Gibofsky, "Need to develop new nonsteroidal anti-inflammatory drug formulations," Clinical Therapeutics, vol. 34, no. 9, pp. 1954-1963, 2012.

[2] D. Kovala-Demertzi, "Recent advances on non-steroidal antiinflammatory drugs, NSAIDs: organotin complexes of NSAIDs," Journal of Organometallic Chemistry, vol. 691, no. 8, pp. 1767-1774, 2006.

[3] M. Starek and J. Krzek, "A review of analytical techniques for determination of oxicams, nimesulide and nabumetone," Talanta, vol. 77, no. 3, pp. 925-942, 2009.

[4] K. Anandakumar, T. Ayyappan, V. Raghu Raman, T. Vetrichelvan, A. S. K. Sankar, and D. Nagavalli, "RP-HPLC analysis of aspirin and clopidogrel bisulphate in combination," Indian Journal of Pharmaceutical Sciences, vol. 69, no. 4, pp. 597-599, 2007.

[5] H. Senyuva and T. Özden, "Simultaneous high-performance liquid chromatographic determination of paracetamol, phenylephrine $\mathrm{HCl}$, and chlorpheniramine maleate in pharmaceutical dosage forms," Journal of Chromatographic Science, vol. 40, no. 2, pp. 97-100, 2002.

[6] P. R. Battu, "Simultaneous RP-HPLC determination of nimesulide and paracetamol in tablets," International Journal of PharmTech Research, vol. 1, no. 3, pp. 514-516, 2009.

[7] H. Chang, W. Ma, and Y. Yang, "HPLC determination of ralated substances of chlophenamine maleate tablets (CPM)," Progress in Modern Biomedicine, 2010.

[8] S. S. Chitlange, P. S. Shinde, G. R. Pawbake, and S. B. Wankhede, "Simultaneous estimation of Thiocolchicoside and Aceclofenac in pharmaceutical dosage form by spectrophotometric and LC method," Der Pharmacia Lettre, vol. 2, pp. 86-93, 2010.

[9] D. De Orsi, L. Gagliardi, A. Bolasco, and D. Tonelli, "Simultaneous determination of triprolidine, pseudoephedrine, paracetamol and dextromethorphan by HPLC," Chromatographia, vol. 43, no. 9-10, pp. 496-500, 1996.
[10] A. P. Dewani, B. B. Barik, S. K. Kanungo, and B. R. Wattyani, "Development and validation of RP-HPLC method for the determination of moxifloxacin in presence of its degradation products," American-Eurasian Journal of Scientific Research, vol. 6, no. 4, pp. 192-200, 2011.

[11] A. M. Di Pietra, R. Gatti, V. Andrisano, and V. Cavrini, "Application of high-performance liquid chromatography with diode-array detection and on-line post-column photochemical derivatization to the determination of analgesics," Journal of Chromatography A, vol. 729, no. 1-2, pp. 355-361, 1996.

[12] V. V. Dighe, R. T. Sane, S. N. Menon, H. N. Tambe, S. Pillai, and V. N. Gokarn, "Simultaneous determination of diclofenac sodium and paracetamol in a pharmaceutical preparation and in bulk drug powder by high-performance thin-layer chromatography," Journal of Planar Chromatography, vol. 19, no. 112, pp. 443-448, 2006.

[13] N. Erk, "Quantitative analysis of chlorpheniramine maleate and phenylephrine hydrochloride in nasal drops by differentialderivative spectrophotometric, zero-crossing first derivative UV spectrophotometric and absorbance ratio methods," Journal of Pharmaceutical and Biomedical Analysis, vol. 23, no. 6, pp. 1023-1031, 2000.

[14] M. Gandhimathi and T. K. Ravi, "High performance liquid chromatographic determination of aspirin and clopidogrel in tablets," Indian Journal of Pharmaceutical Sciences, vol. 69, no. 1, pp. 123-125, 2007.

[15] G. Garg and S. Saraf, "Simultaneous estimation of aceclofenac, paracetamol and chlorzoxazone in tablets," Indian Journal of Pharmaceutical Sciences, vol. 69, no. 5, pp. 692-694, 2007.

[16] V. P. Godse, M. N. Deodhar, A. V. Bhosale et al., "Reverse phase HPLC method for determination of Aceclofenac and Paracetamol in tablet dosage form," Asian Journal of Research in Chemistry, vol. 2, no. 1, pp. 37-40, 2009.

[17] R. Gopinath, S. Rajan, S. N. Meyyanathan, N. Krishnaveni, and B. Suresh, "A RP-HPLC method for simultaneous estimation of paracetamol and aceclofenac in tablets," Indian Journal of Pharmaceutical Sciences, vol. 69, no. 1, pp. 137-140, 2007.

[18] B. Gowramma, S. Rajan, S. Muralidharan, S. N. Meyyanathan, and B. Suresh, "A validated RP-HPLC method for simultaneous estimation of paracetamol and diclofenac potassium in pharmaceutical formulation," International Journal of ChemTech Research, vol. 2, no. 1, pp. 676-680, 2010.

[19] V. Das Gupta and A. R. Heble, "Quantitation of acetaminophen, chlorpheniramine maleate, dextromethorphan hydrobromide, and phenylpropanolamine hydrochloride in combination using high-performance liquid chromatography," Journal of Pharmaceutical Sciences, vol. 73, no. 11, pp. 1553-1556, 1984.

[20] M. A. Haque, M. Shahriar, M. N. Parvin, and S. M. A. Islam, "Validated RP-HPLC method for estimation of ranitidine hydrochloride, domperidone and naproxen in solid dosage form," Asian Journal of Pharmaceutical Analysis, vol. 3, pp. 5963, 2011.

[21] R. Heydari, "A new HPLC method for the simultaneous determination of acetaminophen, phenylephrine, dextromethorphan and chlorpheniramine in pharmaceutical formulations," Analytical Letters, vol. 41, no. 6, pp. 965-976, 2008.

[22] S. D. Jadhav, S. R. Butle, S. D. Patil, and P. K. Jagtap, "Validated stability indicating RP-HPLC method for simultaneous determination and in vitro dissolution studies of thiocolchicoside and diclofenac potassium from tablet dosage form," Arabian Journal of Chemistry, 2011. 
[23] D. Jain, R. N. Kachave, and R. N. Bhadane, "Simultaneous estimation of tramadol hydrochloride, paracetamol and domperidone by RP-HPLC in tablet formulation," Journal of Liquid Chromatography and Related Technologies, vol. 33, no. 6, pp. 786-792, 2010.

[24] R. Joshi and R. Sharma, "Development and validation of RP-HPLC method for simultaneous estimation of three-component tablet formulation containing acetaminophen, chlorzoxazone, and aceclofenac," Analytical Letters, vol. 41, no. 18, pp. 3297-3308, 2008.

[25] K. Kapil, S. Naik, J. Garima, and N. Mishra, "Spectrophotometric method for simultaneous estimation of paracetamol and domperidone in tablet formulation," Asian Journal of Research in Chemistry, vol. 2, no. 2, pp. 112-114, 2009.

[26] A. Karthik, G. Subramanian, A. Ranjith Kumar, and N. Udupa, "Simultaneous estimation of paracetamol and domperidone in tablets by reverse phase HPLC method," Indian Journal of Pharmaceutical Sciences, vol. 69, no. 1, pp. 142-144, 2007.

[27] R. D. Kirchhoefer, "Simultaneous determination of aspirin and salicylic acid in bulk aspirin and in plain, buffered, and entericcoated tablets by high-pressure liquid chromatography with UV and fluorescence detectors," Journal of Pharmaceutical Sciences, vol. 69, no. 10, pp. 1188-1191, 1980.

[28] E. J. Kubiak and J. W. Munson, "Determination of dextromethorphan hydrobromide by high-performance liquid chromatography using ion-pair formation," Journal of Pharmaceutical Sciences, vol. 69, no. 12, pp. 1380-1384, 1980.

[29] S. Kumar, A. Joshi, R. S. Thakur, A. K. Pathak, and K. Shah, "Simultaneous estimation of etoricoxib and thiocolchicoside by RP-HPLC method in combined dosage forms," Acta Poloniae Pharmaceutica, vol. 68, no. 6, pp. 839-843, 2011.

[30] M. Lalitha Devi and K. B. Chandrasekhar, "A validated, specific stability-indicating RP-LC method for moxifloxacin and its related substances," Chromatographia, vol. 69, no. 9-10, pp. 993999, 2009.

[31] A. Marín, E. García, A. García, and C. Barbas, "Validation of a HPLC quantification of acetaminophen, phenylephrine and chlorpheniramine in pharmaceutical formulations: capsules and sachets," Journal of Pharmaceutical and Biomedical Analysis, vol. 29, no. 4, pp. 701-714, 2002.

[32] P. Mishra and A. Dolly, "Simultaneous determination of clopidogrel and aspirin in pharmaceutical dosage forms," Indian Journal of Pharmaceutical Sciences, vol. 68, no. 3, pp. 365-368, 2006.

[33] A. Mitakos and I. Panderi, "A validated LC method for the determination of clopidogrel in pharmaceutical preparations," Journal of Pharmaceutical and Biomedical Analysis, vol. 28, no. 3-4, pp. 431-438, 2002.

[34] M. Momin, P. Yeole, M. Puranik, and S. Wadher, "Reverse phase HPLC method for determination of aceclofenac and paracetamol in tablet dosage form," Indian Journal of Pharmaceutical Sciences, vol. 68, no. 3, pp. 387-389, 2006.

[35] M. S. Mondal, M. A. Haque, and M. S. Islam, "Development and validation of RP-HPLC method for the simultaneous estimation of domperidone and naproxen in tablet dosage form," Journal of Applied Pharmaceutical Science, vol. 1, no. 7, pp. 145-148, 2011.

[36] I. M. Palabiyik and F. Onur, “The simultaneous determination of phenylephrine hydrochloride, paracetamol, chlorpheniramine maleate and dextromethorphan hydrobromide in pharmaceutical preparations," Chromatographia, vol. 66, no. 1, pp. S93-S96, 2007.
[37] H. Patel, B. Suhagia, S. Shah, and I. Rathod, "Determination of etoricoxib in pharmaceutical formulations by HPLC method," Indian Journal of Pharmaceutical Sciences, vol. 69, no. 5, pp. 703705, 2007.

[38] S. R. Pattan, S. G. Jamdar, R. K. Godge et al., "RP-HPLC method for simultaneous estimation of paracetamol and etoricoxib from bulk and tablets," Journal of Chemical and Pharmaceutical Research, vol. 1, no. 1, pp. 329-335, 2009.

[39] H. Y. Aboul-Enein, H. Hoenen, A. Ghanem, and M. Koll, "Reversed phase liquid chromatographic method for the highthroughput analysis of clopidogrel in pharmaceutical formulations using a monolithic silica column," Journal of Liquid Chromatography and Related Technologies, vol. 28, no. 9, pp. 1357-1365, 2005.

[40] V. S. Rajmane, S. V. Gandhi, U. P. Patil, and M. R. Sengar, "Highperformance thin-layer chromatographic determination of etoricoxib and thiocolchicoside in combined tablet dosage form," Journal of AOAC International, vol. 93, no. 3, pp. 783786, 2010.

[41] K. A. Shaikh and A. B. Devkhile, "Simultaneous determination of aceclofenac, paracetamol, and chlorzoxazone by RP-HPLC in pharmaceutical dosage form," Journal of Chromatographic Science, vol. 46, no. 7, pp. 649-652, 2008.

[42] P. Shrivastava, P. Basniwal, D. Jain, and S. Shrivastava, "Concurrent estimation of clopidogrel bisulfate and aspirin in tablets by validated RP-HPLC method," Indian Journal of Pharmaceutical Sciences, vol. 70, no. 5, pp. 667-669, 2008.

[43] K. B. Singh, S. B. Waikar, and S. P. Padmane, "A validated RPHPLC method for the simultaneous estimation of paracetamol and naproxen in tablet formulation," International Journal of Pharmaceutical Sciences and Research, vol. 11, no. 3, pp. 42704275, 2012.

[44] J. Sippel, L. L. Sfair, E. E. S. Schapoval, and M. Steppe, "New high-performance liquid chromatographic method for determination of clopidogrel in coated tablets," Journal of AOAC International, vol. 91, no. 1, pp. 67-72, 2008.

[45] P. R. Subbaiah, M. V. Kumudhavalli, C. Saravanan, M. Kumar, and C. R. Margret, "Method development and validation for estimation of Moxifloxacin $\mathrm{HCl}$ in tablet dosage form by RPHPLC method," Pharmaceutica Analytica Acta, vol. 1, article 109, 2010.

[46] N. Sultana, M. S. Arayne, M. Akhtar, S. Shamim, S. Gul, and M. M. Khan, "High-performance liquid chromatography assay for moxifloxacin in bulk, pharmaceutical formulations and serum: application to in-vitro metal interactions," Journal of the Chinese Chemical Society, vol. 57, no. 4, pp. 708-717, 2010.

[47] S. Sun, G. Liu, and Y. Wang, "Simultaneous determination of acetaminophen, caffeine, and chlorphenamine maleate in paracetamol and chlorphenamine maleate granules," Chromatographia, vol. 64, no. 11-12, pp. 719-724, 2006.

[48] L. Suntornsuk, O. Pipitharome, and P. Wilairat, "Simultaneous determination of paracetamol and chlorpheniramine maleate by micellar electrokinetic chromatography," Journal of Pharmaceutical and Biomedical Analysis, vol. 33, no. 3, pp. 441-449, 2003.

[49] J. C. Tsao and T. S. Savage, "High-performance liquid chromatographic determination of ibuprofen in bulk drug and tablets," Drug Development and Industrial Pharmacy, vol. 11, no. 5, pp. 1123-1131, 1985.

[50] M. Varalakshmi, R. J. Vijaya, and K. KrishnaChaitanya, "RPHPLC method development and validation of domperidone 
maleate," International Journal of Pharmaceutical Research and Development, vol. 3, no. 4, pp. 61-64, 2011.

[51] A. H. Yadav, L. P. Kothapalli, A. N. Barhate et al., "RP-HPLC method for determination of aceclofenac, chlorzoxazone and paracetamol in bulk and pharmaceutical formulation," International Journal Pharmaceutical Research Development, vol. 11, p. 7, 2009.

[52] N. H. Zawilla, M. Abdul Azim Mohammad, N. M. El Kousy, and S. M. El-Moghazy Aly, "Determination of aceclofenac in bulk and pharmaceutical formulations," Journal of Pharmaceutical and Biomedical Analysis, vol. 27, no. 1-2, pp. 243-251, 2002.

[53] T. Hirai, S. Matsumoto, and I. Kishi, "Simultaneous analysis of several non-steroidal anti-inflammatory drugs in human urine by high-performance liquid chromatography with normal solid-phase extraction," Journal of Chromatography B, vol. 692, no. 2, pp. 375-388, 1997.

[54] F. Lapicque, P. Netter, B. Bannwarth et al., "Identification and simulataneous determination of non-steroidal anti-inflammatory drugs using high-performance liquid chromatography," Journal of Chromatography, vol. 496, no. 2, pp. 301-320, 1989.

[55] A. G. Kazemifard and D. E. Moore, "Liquid chromatography with amperometric detection for the determination of nonsteroidal anti-inflammatory drugs in plasma," Journal of Chromatography, vol. 533, pp. 125-132, 1990.

[56] T. Kosjek, E. Heath, and A. Krbavčič, "Determination of nonsteroidal anti-inflammatory drug (NSAIDs) residues in water samples," Environment International, vol. 31, no. 5, pp. 679-685, 2005.

[57] G. González, R. Ventura, A. K. Smith, R. De La Torre, and J. Segura, "Detection of non-steroidal anti-inflammatory drugs in equine plasma and urine by gas chromatography-mass spectrometry," Journal of Chromatography A, vol. 719, no. 1, pp. 251264, 1996.

[58] ICH Guidelines: Validation of Analytical Procedures: Text and Methodology, Q2 (R1), 2005. 

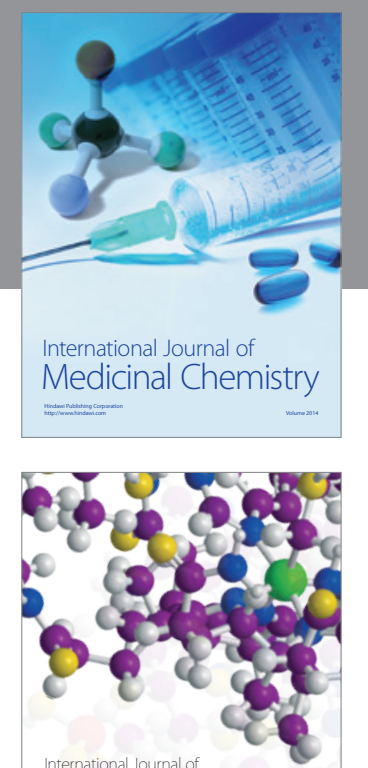

\section{Carbohydrate} Chemistry

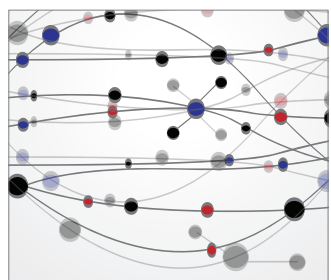

The Scientific World Journal
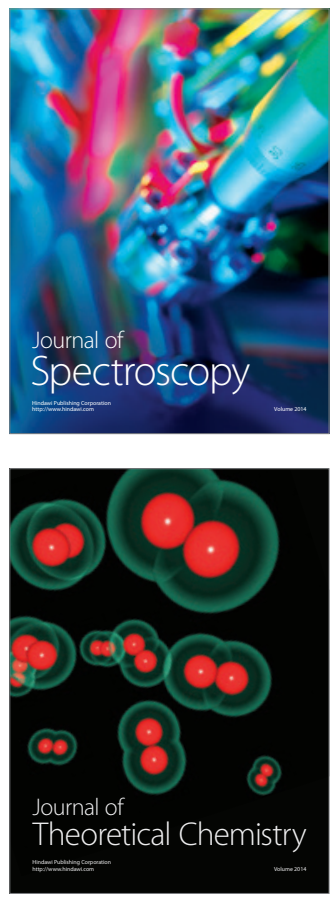
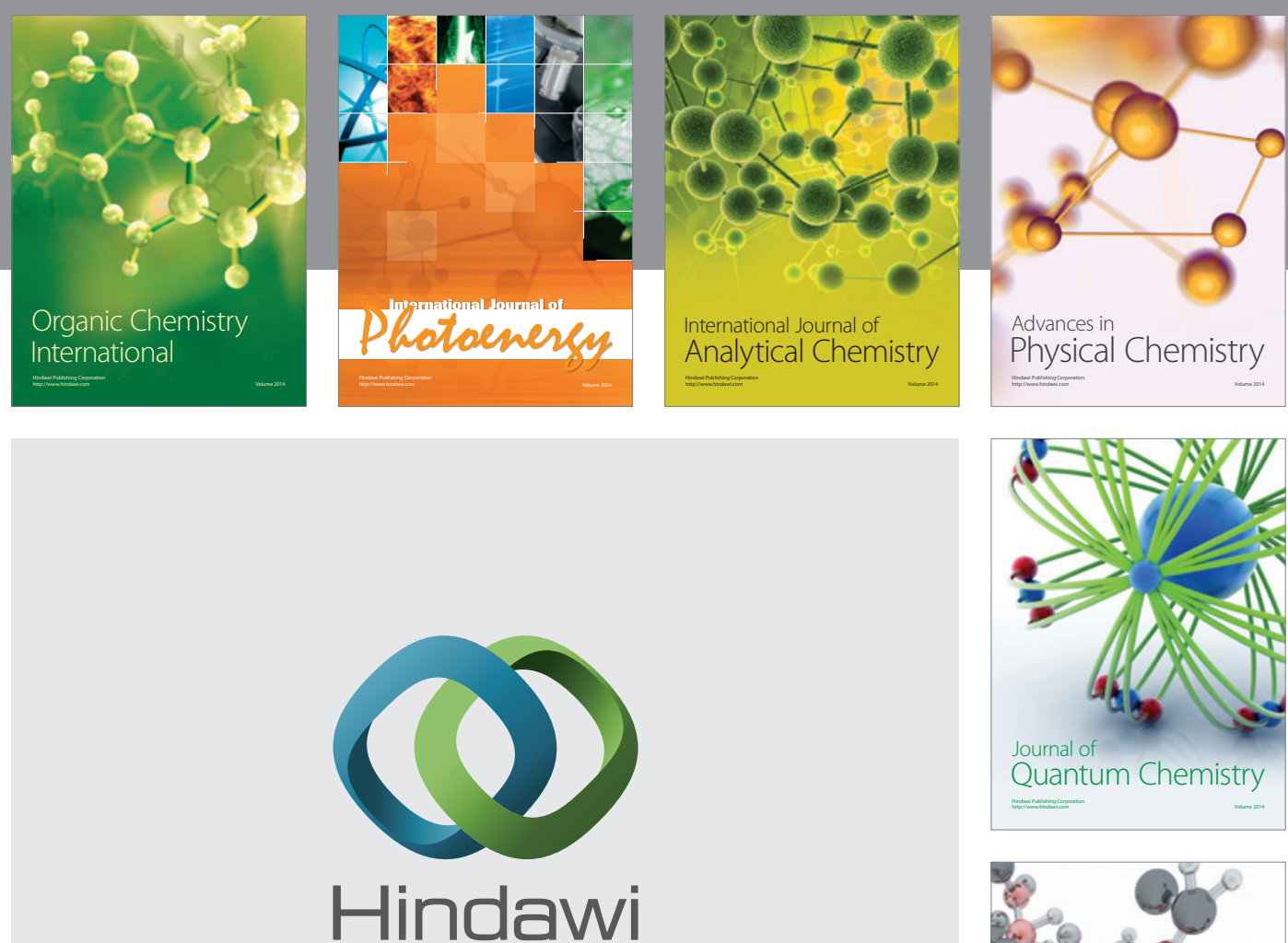

Submit your manuscripts at

http://www.hindawi.com

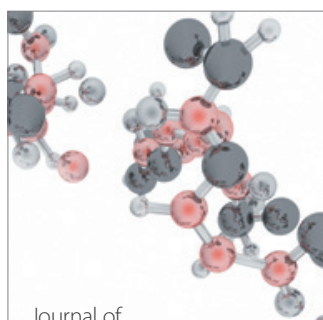

Analytical Methods

in Chemistry

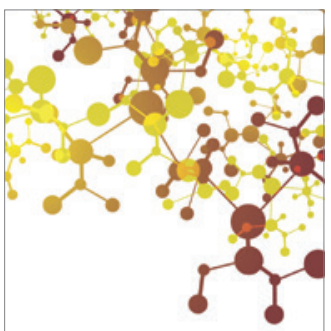

Journal of

Applied Chemistry

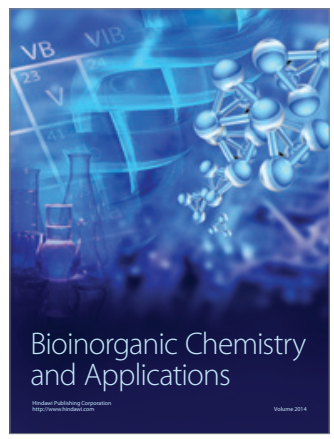

Inorganic Chemistry
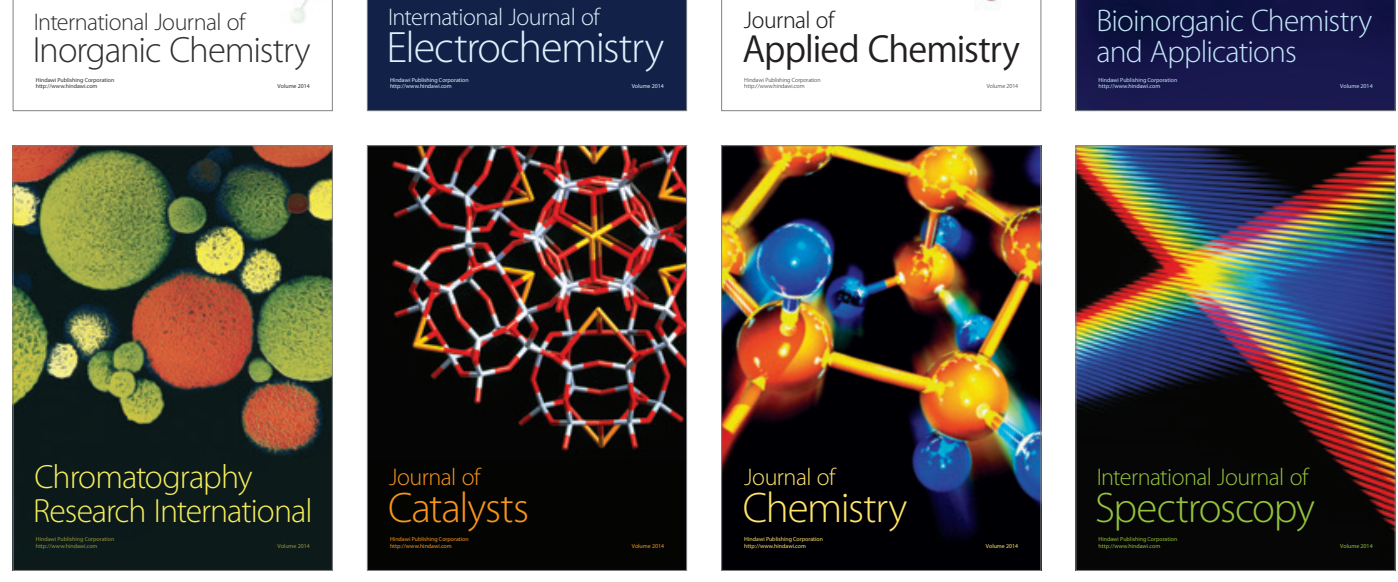